\title{
Impact Of Customer Touch Point Management On Banks' Performance
}

\author{
Agu Godswill Agu \\ Department of Marketing, \\ Abia State University Uturu, Nigeria \\ G. Etuk Samuel \\ Department of Marketing, \\ University of Uyo, Nigeria. \\ Madumere Humphrey Ikenna \\ Department of Marketing, \\ Nnamdi Azikiwe University, Awka, Nigeria
}

\begin{abstract}
The study aimed at assessing the impact of effective customer touch point management on the performance (profitability, patronage level, market share and image) of commercial banks and on customers' satisfaction. The cross-sectional survey research design was adopted while a sample size of 130 respondents made up of First and Zenith Banks Staff and customers in Owerri Metropolis was used. Stated hypotheses were tested using the Chi-square. It was discovered among others that most customer touchpoint management strategies in commercial banks in Owerri were still ineffective and inefficient and that effective customer touchpoint management has significant impact on banks' performance and customers' satisfaction. The study recommended among others that commercial banks should identify and effectively manage the basic customer touchpoints and conduct periodic marketing research to assess customers' view of the efficiency and effectiveness of their touchpoints management efforts.
\end{abstract}

\section{INTRODUCTION}

The Nigerian banking industry is one that undergoes changes from time to time. According to Agu (2008), the sector has experienced the enactment and repeal of many laws which are aimed at ensuring efficiency and effectiveness. The post-consolidation era of Nigerian banking sector is one in which competition has shifted from laying emphasis on banks capitalization to effective management of sensitive customer touch points. This is because all the commercial banks in the sector have at least the minimum capital base of 25 billion Naira. The present bank customers desire to experience and obtain optimum satisfaction from any point of interaction with the financial institutions. A customer has vast possibilities to get in contact with a bank. Some of the touch points identified in a bank include; customer service officers, atmosphere, receipts, events, offerings, financial expert reports, web sites, internet, IT systems, research reports, sponsorships, word of mouth, e-banking, regional office contacts by phone with client service advisors, ATM, etc. In marketing, these are generalized as service evidence.

Wali et al (2008) as quoted by Agu (2008) assert that customer touch points are important to organizations that are customer oriented. It is obvious that these touch points are in existence in virtually all banks. The difficulty in identifying the contact points that are relevant to the success of the firm has resulted in the loss of potential and current customers in most commercial banks in Nigeria. Hence the chronic poor performance of banks even in the new banking dispensation. This situation calls for effective touchpoint management to identify and 
assess the meaning and impact of these contact points with the aim of optimizing performance in all internal and market oriented management decisions. As an aspect of customer relationship management, customer touch point management should take into consideration a company's product, image and branch as they are visible and quite palpable with every touch point the company has with its public (www.stonecreek.com,2009).

This study aims at identifying the touch points that are relevant to the satisfaction of commercial banks' customers in Nigeria and above all evaluating the impact of effective management of these touch points on the overall performance of these banks, using Zenith Bank Plc and First Bank Plc.

\section{Statement of the Problem}

Soludo (2004) states that banks consolidation is a reform designed to ensure a diversified, strong and reliable banking sector capable of ensuring the safety of depositors' funds, a sector that plays active role in economic development and which can compete favourably in the global financial market. In as much as the consolidation exercise has increased depositors' confidence in banks, the performance of these commercial banks is still far behind expectations. According to Scott, (2009), every touch point that leads to a bank needs to impress, motivate and inspire a prospective customer. Ignoring touch points prevents success, caring about them provides valuable competitive advantage (www.customeroptimization.com, 2010). In a null shell, banks' performance have continued to fall below expectation as a result of inability to identify and manage effectively the sensitive customer touch points and this has resulted in inconsistency in delivering effective customer satisfaction.

\section{Research Hypotheses}

These hypotheses were tested in the study:

Ho1: Effective customer touchpoint management does not improve banks' performance.

Ho2: Effective customer touchpoint management does not improve customer satisfaction.

\section{CONCEPTUAL REVIEW}

Customer touch points, according to www.davechaffey.com (2009), refer to those communication channels with which companies interact directly with prospects and customers. Blake (2009) sees it as the sum of all customer interaction with a company over time that ultimately creates or destroys that company's brand value. To Mealey (2009), a touch point is an interaction with a potential customer. Defining customer touch point as an aspect of customer relationship management, Kotler and Keller (2007) assert that a customer touch point is any occasion on which a customer encounters the brand and the product, from actual experience to personal or mass communications to casual observation. Touch points in banks can be web sites, word of mouth, e-banking, contacts by phone, appearance, ATM, etc. (www.wikipedia.com, 2010). Mealey (2009) listed the following high technological interactions as important touch points in an organization: Automated reservation system, Websites, Public Relations, Advertising, T-shirts with logos, coupons and billboards.

It should be noted that the contact points that are relevant for the success of a firm depend considerably on the industry, the product, the service and the target segment. As pointed out in www.stonecreek.com (2009), the messaging of each customer touch point and all of them taken together should be as cohesive as possible for best and lasting impression. The following touch points which are referred to as strategic marketing platform should be well managed: Product/company name, logo, trademark and trade dress, employees, human resources, website, email, and e-mailers, collateral material (printed and written), report/sales communications, leasing strategy and tenanting, marketing calendar, media announcements, 
corporate or product advertising, corporate partnership, sponsorship programmes, promotional items, direct experimental marketing, office presence, etc. Mere presence of all these will neither satisfy the customer nor effectively improve corporate performance if they are not effectively and efficiently managed. Spengler et al (2009) defines touch point as a multi-disciplinary strategic approach which focuses on the optimization of the performance in all internal and market oriented management divisions which cut across marketing, distribution, communication, service, public relations, investor relations or human resources. www.smallbizcrm (2010) defined customer touchpoint management as the development of program to understand key customer touchpoints in order to improve customer relationships which will improve market share, sales, profitability and both customer and employee advocacy. However, we wish to define customer touchpoint management as the planning, implementation and control of programs designed to identify, create and maintain sensitive touch points that will improve customer satisfaction and overall company performance.

Brigman (2010) has given a classification of firms based on their levels of customer touchpoint management. These are:

1. Customer Touchpoint Management Observers: These firms may be doing well, there are opportunities for dramatic improvement of centricity of customers in the organization, but they only observe or monitor customer service trends in the industry as a way of understanding and improving customer touchpoints. These firms will find it difficult to compete; they will experience poor customer satisfaction, etc.

2. Customer Touchpoint Management Followers: These organizations are making progress on improving customer experience and are gaining positive feedback as a result. However, they are still following or imitating the customer touchpoint management strategies of others.

3. Customer Touchpoint Management Leaders: As Customer Touchpoint Management revolution leaders, these organizations are benefiting ahead of their customer experience curve. They excel when compared with their competitors, have improved the relation of both customers and employees, they are committed to improving continuously, touch point performance through an effective touchpoint management plan. Not satisfied, however, the companies still continuously look for internal and external ways of improving touchpoints in order to improve customer centricity and to stay ahead of others.

4. Customer Touchpoint Management Visionary: These organizations are inspiration for the touchpoint revolution both within and outside the industry. They have established benchmarks and best practices for developing and implementing effective Customer Touchpoint Management plan, they have a two-way communication system for both customers and employees, the corporate image of the companies speak about their customer-centricity.

To ensure effective management of touchpoints, Scott (2009) identified the relevance of touchpoint mapping which he defined as an innovative new method of research and analysis that can help a firm to better view and understand organization's relationship with customers by providing comprehensive view of the firm's brand through the lens of customer touchpoints, partners and employees. Touchpoint mapping is important because it:

- Improves conversions

- Increases loyalty and advocacy

- Provides customers' view of an organization

- Provides immediate benefits

- Is dynamic (www.intervosgroup.com 2009). 


\section{METHODOLOGY}

Anyanwu (2000) and Baridam (1990) have given forms of research design which a researcher can adopt to include: survey method (descriptive), experimental and ex-post factor methods. Ezejelue et al (1990) added the historical method. In this work, the cross-sectional survey research design was adopted. Primary and secondary data sources were used. The principal instrument for data collection was structured questionnaire, copies of which were administered on a convenient sample of 130 respondents which were stratified in the ratio of 40:40:50 for First Bank, Zenith Bank and customers respectively. Of this number, a total of 120 were retrieved and found useable.

The scope of the study covered First Bank and Zenith Bank staff and customers in the branches of each of the banks in Owerri Municipal council. Collected data were analyzed using simple percentages and tables, while the Chi-Square was used in testing the stated hypotheses. The Chi-square is given by $\mathrm{X}^{2}=\sum(\mathrm{Fo}-\mathrm{Fe})^{2} / \mathrm{Fe}$.

Where

$\mathrm{X}^{2}=$ Chi-square

Fo $=$ Observed Frequency

$\mathrm{Fe}=$ Expected Frequency

$\sum=$ Sum of

Decision Rule: At 0.05 level of significance, if calculated X2 is greater than X2 critical (value from tables), Reject null hypothesis and Accept the Alternative. If otherwise, Accept null and Reject Alternative hypothesis.

\section{DATA ANALYSIS AND PRESENTATION}

As stated earlier, the 120 copies of questionnaire are hereby presented and analyzed for easy and fast understanding. The questions analyzed were only those that are relevant for the test of hypotheses.

Table 1: Composition of Respondents

\begin{tabular}{|l|c|c|}
\hline Category & Number & Percentage \\
\hline First Bank Staff & 35 & 29.16 \\
Zenith Bank Staff & 35 & 29.16 \\
Customers of both banks & 50 & 41.68 \\
\hline Total & $\mathbf{1 2 0}$ & $\mathbf{1 0 0 . 0 0}$ \\
\hline
\end{tabular}

The table shows that 35 (29.16\%) respondents were staff of First Bank, another 35 (29.16\%) for Zenith Bank. 50 (41.68\%) of total respondents were customers drawn from the two banks.

Table 2: Bio-Data of Respondents

\begin{tabular}{|l|c|c|}
\hline Item & Number & Percentage \\
\hline Sex: & 70 & 58.33 \\
Male & 50 & 41.67 \\
Female & 56 & 46.66 \\
\hline Marital Status: & 64 & 53.34 \\
Married & & 66.66 \\
Single & 50 & 33.34 \\
\hline Age Distribution: & 40 & 43.33 \\
Less than 40 years & & 56.67 \\
41 years and above & 52 & \\
\hline Academic Qualifications: & 68 & \\
Non-degree Holders & & \\
Degree Holders & & \\
\hline
\end{tabular}


From the above table, 70 (58.33\%) were males, 50 (41.67\%) were females, 56 (46.66\%) were married while 64 (53.34\%) were single. 80 (66.66\%) were less than 40 years, $40(33.34 \%)$ from 41 years and above. 52 (43.33\%) had no degree yet (including students) while 68 $(56.67 \%)$ had degree qualifications (including professional qualifications).

Table 3: Basic Touchpoints Identified By Respondents

\begin{tabular}{|l|c|c|}
\hline Option & Number & Percentage \\
\hline Customer care service personnel & 120 & 12.83 \\
\hline Other employees (Dressing etc) & 93 & 9.94 \\
\hline Equipment (ATM, etc) & 120 & 12.83 \\
\hline Interior Design & 120 & 12.83 \\
\hline Bank Outlook & 120 & 12.83 \\
\hline Website, e-banking, etc & 80 & 8.53 \\
\hline Materials- (teller, withdraw) & 78 & 8.34 \\
\hline Promotional strategy & 84 & 8.98 \\
\hline Employ-customer Relation & 120 & 12.83 \\
\hline Total & $\mathbf{9 3 5 . 0 0}$ & $\mathbf{1 0 0 . 0 0}$ \\
\hline
\end{tabular}

From the above table, $120(12.83 \%)$ of the respondents identified customer care service personnel, equipment, intrior design, bank layout, and employee customer relations as the major touchpoints to the banks. Employee dress code had 93 (9.94\%) votes, websites and ebanking had $80(8.55 \%)$ votes, materials such as withdrawal slip, teller, etc. had 78 (8.34\%) votes while promotional strategy had $84(8.98 \%)$ votes.

Table 4: Respondents' Assessment of Identified Touchpoints

\begin{tabular}{|l|c|c|}
\hline Option & Number & Percentage \\
\hline Very Satisfactory & 46 & 38.33 \\
\hline Satisfactory & 57 & 47.50 \\
\hline Unsatisfactory & 15 & 12.50 \\
\hline Very Unsatisfactory & 2 & 1.66 \\
\hline Total & $\mathbf{1 2 0}$ & $\mathbf{1 0 0 . 0 0}$ \\
\hline
\end{tabular}

The table above shows that 46 (38.33\%0 respondents disclosed that touchpoints of the banks were very satisfactory. $57(47.50 \%)$ rated them satisfactory, $15(12.50)$ and $2(1.66 \%)$ rated them unsatisfactory and very unsatisfactory respectively.

Table 5: Respondents' Rating of Management of Banks Touchpoints

\begin{tabular}{|l|c|c|}
\hline Option & Number & Percentage \\
\hline Very Effective/efficient & 22 & 18.33 \\
\hline Effective/efficient & 41 & 34.16 \\
\hline Ineffective/Inefficient & 40 & 33.33 \\
\hline Very Ineffective/Inefficient & 17 & 14.16 \\
\hline Total & $\mathbf{1 2 0}$ & $\mathbf{1 0 0 . 0 0}$ \\
\hline
\end{tabular}

The table above shows that 22 (18.33\%) respondents said that management of banks' touchpoints was very effective/efficient. 41 (34.16\%) rated it effective/efficient, 40 (33.33\%) rated it ineffective/inefficient, while 17 (14.16\%) rated it very ineffective/inefficient. 
Table 6: Rating of impact Touchpoints Management on performance indexes

\begin{tabular}{|l|c|c|c|c|c|c|}
\hline Option & $\begin{array}{c}\text { Very } \\
\text { High }\end{array}$ & High & $\begin{array}{c}\text { Neither High } \\
\text { nor Low }\end{array}$ & Low & Very Low & Total \\
\hline Profitability & 120 & - & - & - & - & 120 \\
\hline Patronage & 98 & 22 & - & - & - & 120 \\
\hline Market Share & 110 & 10 & - & - & - & 120 \\
\hline Company Image & 86 & 34 & - & - & - & 120 \\
\hline Total & $\mathbf{4 1 4}$ & $\mathbf{6 6}$ & - & - & - & $\mathbf{4 8 0}$ \\
\hline Percentage & $\mathbf{8 6 . 2 5}$ & $\mathbf{1 3 . 7 5}$ & - & - & - & $\mathbf{1 0 0 . 0 0}$ \\
\hline
\end{tabular}

From the table above, a total of 414 (86.25\%) votes were recorded from those who rated the impact of effective/efficient touchpoint management on performance (profitability, patronage, market share and company image) "very high. 66 (13.75\%) votes went for "High", while no votes went for "Neither High nor Low", "Low" and "Very Low" respectively.

Table 7: Whether Effective Touchpoint Management Improves Customer Satisfaction

\begin{tabular}{|l|c|c|}
\hline Option & Frequency & Percentage \\
\hline Strongly Agreed & 108 & 90.00 \\
\hline Agreed & 12 & 10.00 \\
\hline Neither Agreed nor Disagreed & 40 & 33.33 \\
\hline Disagreed & 17 & 14.16 \\
\hline Strongly Disagreed & & \\
\hline Total & $\mathbf{1 2 0}$ & $\mathbf{1 0 0 . 0 0}$ \\
\hline
\end{tabular}

From the table, $108(90.00 \%)$ of the respondents strongly agreed that effective customer touchpoint management has great impact on customer satisfaction. 12 (10.00\%) agreed to this, while none voted for "Neither agreed nor disagreed" "Disagreed" and "Strongly Disagreed" respectively.

\section{Test of Hypotheses}

\section{Hypothesis One:}

H0: Effective customer touchpoint management does not improve bank performance.

H1: Effective customer touchpoint management improves bank performance.

Table 8: Chi-Square Calculation of table 6

\begin{tabular}{|l|c|c|c|c|c|}
\hline Option & Fo & Fe & Fo - Fe & (Fo-Fe) $^{\mathbf{2}}$ & $\mathbf{( F o - F e}^{\mathbf{2}} / \mathbf{F e}$ \\
\hline Very High & 103 & 24 & 79 & 6241 & 260.04 \\
\hline High & 17 & 24 & -12 & 144 & 1.20 \\
\hline Neither High nor Low & 0 & 24 & -24 & 576 & 24.00 \\
\hline Low & 0 & 24 & -24 & 576 & 24.00 \\
\hline Very Low & 0 & 24 & -24 & 576 & 24.00 \\
\hline Total & $\mathbf{1 2 0}$ & $\mathbf{1 0 0 . 0 0}$ & & $\mathbf{X}^{\mathbf{2}}$ & $\mathbf{3 3 3 . 2 4}$ \\
\hline
\end{tabular}

$\mathrm{X}^{2}$ calculated $=333.24$

$\mathrm{X}^{2}$ critical at0.005 level of significance and $\mathrm{df}(4-1) \times(5-1)=21.03$

Decision: Since $\mathrm{X}^{2}$ calculated (333.24) is greater than $\mathrm{X}^{2}$ critical (21.03), therefore, Reject null hypothesis and Accept Alternative hypothesis that effective customer touchpoint management improves bank performance.

\section{Hypothesis Two:}

H0: Effective customer touchpoint management does not improve customer satisfaction.

H1: Effective customer touchpoint management improves customer satisfaction.

Table 7 is used to test this hypothesis. 
Table 9: Chi-Square Calculation of table 7

\begin{tabular}{|l|c|c|c|c|c|}
\hline Option & Fo & Fe & Fo - Fe & (Fo-Fe) $^{\mathbf{2}}$ & (Fo-Fe) $^{2} /$ Fe \\
\hline Very High & 108 & 24 & 84 & 7056 & 294.00 \\
\hline High & 12 & 24 & -12 & 144 & 6.00 \\
\hline Neither High nor Low & 0 & 24 & -24 & 576 & 24.00 \\
\hline Low & 0 & 24 & -24 & 576 & 24.00 \\
\hline Very Low & 0 & 24 & -24 & 576 & 24.00 \\
\hline Total & $\mathbf{1 2 0}$ & $\mathbf{1 0 0 . 0 0}$ & & $\mathbf{X}^{\mathbf{2}}$ & $\mathbf{3 7 2 . 0 0}$ \\
\hline
\end{tabular}

$\mathrm{X} 2$ calculated $=372.00$

$\mathrm{X} 2$ critical at 0.005 level of significance and $\mathrm{df}(4)=9.49$

Decision: Since $X^{2}$ calculated (372.00) is greater than $X^{2}$ critical (9.49), we therefore, Reject null hypothesis and Accept Alternative hypothesis that effective customer touchpoint management improves customer satisfaction.

\section{SUMMARY OF FINDINGS}

The following major findings were made in this work:

1. It was discovered that the following customer touchpoints appeal most to bank customers:

- Customer service personnel approach

- Nature of technological equipment

- Interior designs

- Bank outlook

2. That these touchpoints have significant impact on the satisfaction of bank customers.

3. That most banks touchpoint management is still ineffective and inefficient.

4. That effective customer touchpoint management improves bank performance in the area of increased profitability, market share, patronage and company image.

\section{CONCLUSION}

Every angle of a banking firm is a touchpoint to a specific segment of its publics. Identifying the touchpoints that appeal to customers most and that can improve firm's performance and managing them effectively will position a bank than others in the industry.

\section{RECOMMENDATIONS}

Based on the findings of this work, the following recommendations are hereby made:

1. Commercial banks should endeavour to identify and effectively manage the basic customer touchpoints that will improve customer satisfaction and advocacy as this will help improve profitability, patronage, market share and company image.

2. Constant marketing research should be conducted to evaluate the impact or place of each customer touchpoint on the satisfaction level of customers. This will dictate the constant points where attention will be paid most. Touchpoint mapping becomes the best strategy here.

3. Effective customer touchpoint management programme should be designed to plan, implement and control every activity at each touchpoint.

4. Firms should strive to reach the CTM visionary stage and try to maintain this position as this will help improve performance through customers' advocacy and company goodwill. 


\section{References}

Agu, G. A.(2008) “Banking Services”, Contemporary Book on Services Marketing, Owerri: Avan Global Press. Anyanwu A (2000), Research Methodology in Administrative Sciences,Port Harcourt: Belk Publishers.

Blake, B (2010), “The Customer Lens: An Approach to Customer Touchpoint Management."www.About.com Brigman, H (2010), “Customer Touchpoint Management - Find out where your firm stands”www.google.com Ezejeluo, A. C. and Ogwo, E. O(1990), Basic Principles in Managing Research Projects, Onitsha: African FEB Publishers.

Kotler, P and Keller, K. L. (2007), Marketing Management, 12 th ed., New Delhi: Prentice Hall of India Mealey, I (2009), “Capitalizing on every opportunity to Interact with Customers”, About.com Guide. Scott G (2009) “Look Like a Multimillion Dollar Brand”www.Entrepreneur.com

Soludo, C. C. (2004) “Consolidating the Nigerian Banking Industry to Meet the Development Challenges of the 21st Century” CBN Bulletin, July.

Spengler, C. and Worth, W. (2009) “360 Touchpoint Analysis: Maximizing the Impact of Marketing and Sales Activities."www.accelenem.com 